\title{
SISTEM PENDUKUNG KEPUTUSAN DALAM MENENTUKAN JUMLAH PRODUKSI SERAGAM MENGGUNAKAN METODE FUZZY TSUKAMOTO
}

\author{
${ }^{[1]}$ Abdi Pandu Kusuma, ${ }^{[2]}$ Wahyu Dwi Puspitasari, ${ }^{[3]}$ Tio Gustiyoto \\ ${ }^{[1]}$ Universitas Islam Balitar, ${ }^{[2]}$ Universitas Islam Balitar, ${ }^{[3]}$ Universitas Islam Balitar
}

\begin{abstract}
Abstrak: Penentuan jumlah produksi merupakan salah satu proses pengambilan keputusan perusahaan yang cukup penting. Salah satu kesulitan penentuan jumlah produksi terjadi manakala berhadapan dengan ketidakpastian. Sistem Pendukung Keputusan (SPK) ini dikembangkan bertujuan untuk membantu menentukan jumlah produksi seragam berdasarkan data persediaan dan jumlah permintaan. Penelitian ini menggunakan metode fuzzy Tsukamoto yang menghasilkan suatu model dari suatu sistem yang mampu memberikan rekomendasi jumlah produksi yang diterapkan dalam suatu sistem pendukung keputusan. Metode fuzzy Tsukamoto dalam menentukan jumlah produksi berdasarkan 3 variabel yaitu jumlah permintaan, jumlah persediaan, dan jumlah produksi. Setiap variabel terdiri dari dua himpunan yang di kombinasikan hingga diperoleh empat aturan fuzzy, yang selanjutnya digunakan dalam tahap inferensi. Pada tahap inferensi, dicari nilai keanggotaan anteseden $(\alpha)$ dan nilai perkiraan jumlah produksi (z) dari setiap aturan. Jumlah barang yang akan diproduksi (Z) dicari dengan metode defuzzifikasi rata-rata terpusat. Pengujian akan dilakukan secara obyektif dimana SPK diuji secara langsung ke lapangan dan mengisi kuesioner mengenai kepuasan dengan kandungan point syarat user friendly dan dibagikan kepada karyawan dengan mengambil sample sebanyak 10 orang. Dengan adanya pengujian ini dapat di ketahui bahwa fitur yang telah disediakan mudah dipelajari dan mudah dipahami.
\end{abstract}

Kata kunci: Fuzzy Tsukamoto, Produksi, Pengabilan Keputusan.

\section{Pendahuluan}

Sekarang ini hampir semua perusahaan dihadapkan pada suatu masalah yaitu adanya tingkat persaingan yang semakin kompetitif. Hal ini mengharuskan perusahaan untuk merencanakan atau menentukan jumlah produksi, agar dapat memenuhi permintaan pasar dengan tepat waktu, juga dalam jumlah yang sesuai, sehingga diharapkan keuntungan perusahaan akan meningkat. Pada dasarnya penentuan jumlah produksi ini direncanakan untuk memenuhi tingkat produksi guna memenuhi tingkat penjualan yang direncanakan atau tingkat permintaan pasar. Terkadang banyaknya jumlah permintaan pasar tidak sebanding dengan jumlah produksi yang dihasilkan oleh perusahaan. Sehingga timbul ketidakpastian dalam menentukan jumlah produksi tersebut. Dengan adanya ketidakpastian, maka perlu menentukan jumlah produksi yang optimum.

Bapak Agus selaku pemilik usaha konveksi sumber karya mengatakan bahwa perusahaannya mengalami masalah dalam produksi. Kebutuhan konsumen yang tidak pasti dari waktu ke waktu (dalam arti konsumsi per hari bahkan per bulannya selalu berbeda) menyebabkan terjadinya hubungan antara pengeluaran, persediaan dan jumlah produksi antara satu dengan yang lain menjadi saling berkaitan. Banyaknya perubahan jumlah yang akan diproduksi akan dipengaruhi oleh pengeluaran dan persediaan di gudang perusahaan tersebut. Menanggapi jumlah permintaan seragam yang selalu berubah-ubah sewaktuwaktu, menjadi permasalahan untuk menentukan jumlah produksi seragam yang tepat untuk memenuhi permintaan pasar tepat waktu dengan jumlah yang sesuai. Ketidakpastian jumlah produksi seragam ini 
sangat beresiko dalam proses mempertahankan kualitas seragam, sehingga penanganan untuk menanggulangi kerawanan produksi seragam perlu dilakukan.

Banyak cara yang dapat dilakukan untuk menyelesaikan masalah-masalah tersebut, salah satunya adalah dengan menggunakan logika fuzzy (logika samar) karena logika fuzzy tidak kaku dengan nilai keanggotaan yang dimilikinya (Kusumadewi \& Purnomo, 2004). Logika fuzzy merupakan logika yang berhadapan dengan konsep kebenaran sebagian, dimana logika klasik menyatakan bahwa nilai kebenaran dapat diekspresikan dalam istilah binary (0 atau 1). Sedangkan logika fuzzy memungkinkan nilai keanggotaan antara 0 dan 1. Dengan menggunakan metode tersebut diharapkan dapat membantu perusahaan dalam menentukan jumlah produksi.

Ada tiga metode dalam sistem inferensi fuzzy yang dapat digunakan untuk menentukan jumlah produksi, yaitu: metode Tsukamoto, metode Mamdani, dan metode Sugeno (Setiaji, 2009). Metode yang akan digunakan dalam penelitian ini adalah metode Tsukamoto. Metode ini dipilih karena setiap konsekuen pada aturan yang berbentuk IF-THEN direpresentasikan dengan himpunan fuzzy dengan fungsi keanggotaan yang monoton. Sebagai hasilnya, output dari setiap aturan diberikan secara tegas berdasarkan $\alpha$ (alpa), kemudian diperoleh hasil akhir dengan menggunakan rata-rata terpusat. Penggunaan Fuzzy Inference System (FIS) metode Tsukamoto dalam Sistem Pendukung Keputusan (SPK) dapat memberikan nilai akhir yang valid karena perubahan selisih angka sekecil apapun nilai survei akan mempengaruhi nilai akhir dari perhitungan (Yuniardi, 2013).

Variabel input dalam metode tsukamoto meliputi hari dimulainya produksi, masa produksi, persediaan barang maksimum satu periode tertentu, persediaan barang minimum satu periode tertentu, permintaan maksimum satu periode tertentu, permintaan minimum satu periode tertentu, produksi maksimum satu periode tertentu, produksi minimum satu periode tertentu, permintaan saat ini, dan persediaan saat ini (Daihani, 2001). Kemudian SPK akan mengolah data-data tersebut dan akan menampilkan keluaran (output) berupa jumlah barang yang akan diproduksi.

Berdasarkan latar belakang di atas, dalam skripsi ini penulis melakukan penelitian dan membuat aplikasi berbasis WEB dengan judul "Sistem Pendukung Keputusan Dalam Menentukan Jumlah Produksi Seragam Menggunakan Metode Fuzzy Inference System (FIS) Tsukamoto”. Dengan menggunakan SPK dan metode FIS tsukamoto diharapkan mampu menyelesaikan permasalahan yang kompleks melalui pendekatan sistem dan pengintegrasian secara deduktif. Dalam penelitian yang lebih kompleks dan terstruktur banyak sekali langkah-langkah yang harus di jalani sehingga dapat memberikan keputusan yang baik. Dengan mengumpulkan data-data hasil penelitian yang lebih kompleks aplikasi yang di buat mampu berjalan sempurna untuk menentukan jumlah produksi seragam.

\section{A. Tempat dan Waktu Penelitian}

\section{Metode Penelitian}

Adapun waktu dan tempat penelitian dalam menyelesaikan skripsi yang berjudul sistem pendukung keputusan dalam menentukan jumlah produksi seragam menggunakan metode fuzzy inference system Tsukamoto yang penulis laksanakan mulai tanggal 1 Mei 2017 sampai 6 Mei 2017. Penelitian dilakukan pada CV.Sumber Karya yang merupakan perusahaan konveksi seragam dalam skala menengah yang beralamatkan di jl. Surga RT.06/RW.01 blok 2 no 10 Kecamatan Ponggok Kabupaten Blitar.

\section{B. Identifikasi Permasalahan}

Indentifikasi Permasalahan dilakukan dengan pengidentifikasian kendala atau permasalahan yang terjadi, diantaranya yaitu : Pengembangkan sebuah SPK dalam menentukan jumlah produksi seragam menggunakan metode FIS Tsukamoto, Penerapan metode FIS Tsukamoto pada SPK dalam menentukan jumlah produksi seragam dan Pengujian SPK dalam menentukan jumlah produksi seragam menggunakan 
metode FIS Tsukamoto yang dilakukan oleh pemilik perusahaan dengan mengisi kuisioner yang telah disediakan.

Adapun penyebab terjadinya permasalahan diatas diantaranya : Belum adanya sebuah SPK dalam menentukan jumlah produksi seragam, Kebutuhan konsumen yang tidak pasti dari waktu ke waktu dan Banyaknya perubahan jumlah produksi yang mempengaruhi pengeluaran dan persediaan di gudang perusahaan tersebut.

\section{Pengumpulan Data}

Data yang diperlukan dalam penyusunan skripsi ini bertujuan untuk mendapatkan informasi yang relative lengkap sebagai bahan yang dapat mendukung kebenaran materi, uraian dan pembahasan. Oleh karena itu, sebelum penyusunan skripsi ini dilakukan riset atau penelitian terlebih dahulu untuk menjaring data serta informasi yang terkait. Metode pengumpulan data yang dianggap sesuai dengan permasalahan yang ada dalam pelaksanaan penyusunan sekripsi ini adalah metode kualitatif dimana dalam pelaksanaanya dilakukan tahapan sebagai berikut.

\section{Pengamatan dan Observasi}

Kegiatan pengamatan observasi dilakukan untuk mengetahui keadaan di lapangan dari tempat penelitian yang dilakukan oleh peneliti dalam membangun sebuah sistem pendukung kepusan dalam menentukan jumlah produksi seragam. Kegiatan observasi ini dilakukan di CV.Sumber Karya j1.Surga kecamatan ponggok kabupatem blitar.

\section{Wawancara}

Tahap wawancara bertujuan untuk mengetahui kebutuhan sistem dari segi arsitektur aplikasi, teknologi yang digunakan, serta pemanfaatannya. Pertanyaan wawancara yang di ajukan kepada bapak Agus selaku pemilik perusahaan konveksi di CV.Sumber Karya.

\section{Studi Pustaka}

Segala usaha yang dilakukan oleh peneliti untuk menghimpun informasi yang relevan dengan topik atau masalah yang akan atau sedang diteliti. Informasi itu dapat diperoleh dari buku-buku ilmiah, laporan penelitian, karangan-karangan ilmiah, tesis dan disertasi, peraturan-peraturan, ketetapanketetapan, buku tahunan, ensiklopedia, dan sumber-sumber tertulis baik tercetak maupun elektronik lain. Studi kepustakaan merupakan suatu kegiatan yang tidak dapat dipisahkan dari suatu penelitian. Teoriteori yang mendasari masalah dan bidang yang akan diteliti dapat ditemukan dengan melakukan studi kepustakaan. Selain itu seorang peneliti dapat memperoleh informasi tentang penelitian-penelitian sejenis atau yang ada kaitannya dengan penelitiannya. Dan penelitian-penelitian yang telah dilakukan sebelumnya. Dengan melakukan studi kepustakaan, peneliti dapat memanfaatkan semua informasi dan pemikiran-pemikiran yang relevan dengan penelitiannya.

\section{Analisis Metode Fuzzy Tsukamoto}

Di dalam metode ini, secara umum terdapat tiga langkah untuk menentukan jumlah produksi berdasarkan data persediaan dan data permintaan dengan metode Tsukamoto, yaitu: fuzzifikasi, inferensi, dan defuzzifikasi (menentukan output crisp).

\section{Contoh kasus:}

CV.Sumber Karya adalah suatu perusahaan yang memproduksi seragam. Dari data mulai tanggal 1 Mei 2017 sampai 6 Mei 2017. Berdasarkan Tabel 1 diketahui jumlah permintaan saat ini, yaitu bulan Mei 
2017 sebanyak 500 buah seragam, dan persediaan masih 50 buah. Berapa seragam yang harus diproduksi pada selanjutnya ?

Setelah aturan-aturan fuzzy terbentuk selanjutnya adalah menentukan nilai tertinggi dan nilai terendah dari semua atribut yang di pilih dengan menggunakan fungsi query min dan max untuk setiap atribut.dari fungsi tersebut didapat nilai tertinggi dan nilai terendah sebagai berikut.

TABEL 1

Data Permintaan , Persediaan, dan Produksi Seragam

\begin{tabular}{cc}
\hline Data Seragam & Seragam $($ Buah ) \\
\hline Permintaan Maksimum & 614 \\
Permintaan Minimum & 434 \\
Persediaan Maksimum & 93 \\
Persediaan Minimum & 30 \\
Produksi Maksimum & 650 \\
Produksi Minimum & 450 \\
\hline
\end{tabular}

Setelah menentukan nilai tertinggi dan terendah dari semua atribut yang di pilih langkah selanjutnya dalam menyelesaikan permasalahaan yamg telah di jelaskan yaitu dengan menggunakanmetode Tsukamoto secara manual, ada beberapa langkah yang ditempuh.Langkah-langkah tersebut adalah: mendefinisikan variabel fuzzy, inferensi, dan defuzifikasi.

\section{Memodelkan variabel fuzzy (Fuzzyfikasi)}

Ada 3 variabel fuzzy yang akan dimodelkan, yaitu: variabel permintaan, variabel persediaan, dan variabel produksi barang.

a. Variabel Permintaan terdiri atas 2 himpunan fuzzy, yaitu TURUN dan NAIK. Fungsi keanggotaan himpunan fuzzy TURUN dan NAIK dari himpunan fuzzy Permintaan adalah :

$$
\begin{gathered}
\mu_{\text {PItTURUN }}[x]=\left\{\begin{array}{cc}
1 & , x \leq 434 \\
\frac{614-x}{614-434} & , 434 \leq x \leq 614 \\
0 & , x \geq 614
\end{array}\right. \\
\mu_{\text {PmtNAIK }}[x]=\left\{\begin{array}{cc}
0 & , x \leq 434 \\
\frac{x-434}{614-434}, & 434 \leq x \leq 614 \\
1 & , x \geq 614
\end{array}\right.
\end{gathered}
$$

Nilai keanggotaan himpunan TURUN dan NAIK dari variabel Permintaan bisa dicari dengan:

$$
\begin{aligned}
& \mu_{\text {PmtTURUN }}[500]=(614-500) / 180 \\
& \mu_{P \text { TINAIK }}[500]=(500-434) / 180
\end{aligned}
$$

b. Variabel Persediaan terdiri atas 2 himpunan fuzzy, yaitu SEDIKIT dan BANYAK. Fungsi keanggotaan himpunan fuzzy SEDIKIT dan BANYAK dari himpunan fuzzy Persediaan adalah : 


$$
\begin{aligned}
& \mu_{\text {PSdSEDIKIT }}[y]=\left\{\begin{array}{cc}
1 & , y \leq 30 \\
\frac{93-y}{93-30} & , 30 \leq y \leq 93 \\
0 & , y \geq 93
\end{array}\right. \\
& \mu_{P S d B A N Y A K}[y]=\left\{\begin{array}{cc}
0 & , y \leq 30 \\
\frac{y-30}{93-30} & , 30 \leq y \leq 93 \\
1 & , y \geq 93
\end{array}\right.
\end{aligned}
$$

Nilai Keanggotaan Himpunan SEDIKIT, dan BANYAK dari variabel Persediaan dapat dicari dengan:

$$
\begin{aligned}
& \mu_{\text {PSdSEDIKIT }}[50]=(93-50) / 63 \\
& \mu_{P S d B A N Y A K}[50]=(50-30) / 63
\end{aligned}
$$

c. Variabel Produksi terdiri atas 2 himpunan fuzzy, yaitu BERKURANG dan BERTAMBAH. Fungsi keanggotaan himpunan fuzzy BERKURANG dan Bertambahdari himpunan fuzzy Produksi adalah :

$$
\begin{aligned}
& \mu_{\text {PrBERKURANG }}[z]=\left\{\begin{array}{cc}
1 & , z \leq 450 \\
\frac{650-z}{650-450} & , 450 \leq z \leq 650 \\
0 & , z \geq 650
\end{array}\right. \\
& \mu_{\text {PrBERTAMBAH }}[z]=\left\{\begin{array}{cc}
0 & , z \leq 450 \\
\frac{z-450}{650-450} & , 450 \leq z \leq 650 \\
1 & , z \geq 650
\end{array}\right.
\end{aligned}
$$

Setelah semua himpunan fuzzy ditentukan, kemudian dicari nilai keanggotaan himpunan fuzzy dari tiap variabel. Berdasarkan kombinasi himpunan fuzzy yang telah ditentukan, kemudian nilai keanggotaan himpunan fuzzy dari tiap variabel digunakan pada tahap selanjutnya, yaitu tahap inferensi.

\section{Inferensi}

a. [R1] IF Permintaan TURUN And Persediaan BANYAK THEN Produksi Barang BERKURANG;

Nilai keanggotaan anteseden untuk aturan fuzzy [R1] yang dinotasikan dengan $\alpha 1$ diperoleh dengan rumus sebagai berikut.

$$
\begin{aligned}
\alpha 1 & =\mu_{P m t T U R U N \cap P S d B A N Y A K} \\
& =\min \left(\mu_{P m t T U R U N}[x], \mu_{P S d B A N Y A K}[y]\right) \\
& =-(0.63333333333333,0.31746031746032) \\
& =-0.31746031746032
\end{aligned}
$$

Menurut fungsi keanggotaan himpunan Produksi Barang BERKURANG dalam aturan fuzzy [R1] maka nilai z1 adalah:

$$
\begin{aligned}
\mathrm{z} 1 & =650-\alpha 1(650-450) \\
& =586.50793650794
\end{aligned}
$$


b. [R2] IF Permintaan TURUN And Persediaan SEDIKIT THEN Produksi Barang BERKURANG;

Nilai keanggotaan anteseden untuk aturan fuzzy [R2] yang dinotasikan dengan $\alpha 2$ diperoleh dengan rumus sebagai berikut:

$$
\begin{aligned}
\alpha 2 & =\mu_{\text {PmtTURUN PSASEDIKIT }} \\
& =\min \left(\mu_{\text {PmtTURUN }}[x], \mu_{\text {PSdSEDIKIT }}[y]\right) \\
& =-(0.63333333333333,0.68253968253968) \\
& =-0.63333333333333
\end{aligned}
$$

Menurut fungsi keanggotaan himpunan Produksi Barang BERKURANG dalam aturan fuzzy [R2] maka nilai z2 adalah:

$$
\begin{aligned}
\mathrm{z} 2 & =650-\alpha 2(650-450) \\
& =523.33333333333
\end{aligned}
$$

c. [R3] IF Permintaan NAIK And Persediaan BANYAK THEN Produksi Barang BERTAMBAH;

Nilai keanggotaan anteseden untuk aturan fuzzy [R3] yang dinotasikan dengan $\alpha 3$ diperoleh dengan rumus sebagai berikut:

$$
\begin{aligned}
\alpha 3 & =\mu_{P m t N A I K \cap P S d B A N Y A K} \\
& =\min \left(\mu_{P m t N A I K}[x], \mu_{P s d B A N Y A K}[y]\right) \\
& =-(0.36666666666667,0.31746031746032) \\
& =-0.31746031746032
\end{aligned}
$$

Menurut fungsi keanggotaan himpunan Produksi Barang BERTAMBAH dalam aturan fuzzy [R3] maka nilai z3 adalah:

$$
\begin{aligned}
\mathrm{z} 3 & =\alpha 3(650-450)+450 \\
& =513.49206349206
\end{aligned}
$$

d. [R4] IF Permintaan NAIK And Persediaan SEDIKIT THEN Produksi Barang BERTAMBAH; Nilai keanggotaan anteseden untuk aturan fuzzy [R4] yang dinotasikan dengan $\alpha 4$ diperoleh dengan rumus sebagai berikut:

$$
\begin{aligned}
\alpha 4 & =\mu_{P m T N A I K \cap P S d S E D I K I T} \\
& =\min \left(\mu_{P \operatorname{miNAIK}}[x], \mu_{P S d S E D I K I T}[y]\right) \\
& =-(0.36666666666667,0.68253968253968) \\
& =-0.36666666666667
\end{aligned}
$$

Menurut fungsi keanggotaan himpunan Produksi Barang BERTAMBAH dalam aturan fuzzy [R4] maka nilai $\mathrm{z} 4$ adalah:

$$
\begin{aligned}
\mathrm{z} 4 & =\alpha 4(650-450)+450 \\
& =523.33333333333
\end{aligned}
$$

\section{Menentukan Output Crisp (Defuzzifikasi)}

Pada metode Tsukamoto, untuk menentukan output crisp, digunakan defuzifikasi rata-rata terpusat, yaitu:

$$
\begin{aligned}
\mathrm{Z} & =\frac{\alpha 1 * z 1+\alpha 2 * z 2+\alpha 3 * z 3+\alpha 4 * z 4}{\alpha 1+\alpha 2+\alpha 3+\alpha 4} \\
& =\frac{0.317 * 586.507+0.633 * 523.333+0.317 * 513.492+0.366 * 523.333}{0.317+0.633+0.317+0.366} \\
& =\frac{872.53968253968}{1.6349206349206} \\
& =\mathbf{5 3 4}
\end{aligned}
$$


Jadi, menurut perhitungan dengan metode Tsukamoto diatas, jumlah rekomendasi produksi seragam yang harus diproduksi perusahaan CV.Sumber Karya pada bulan selanjutnya sebanyak 534 buah.

\section{E. Metode Perancangan Sistem}

Perancangan sistem adalah suatu fase dimana diperlukan suatu keahlian perancangan untuk elemen-elemen komputer yang akan mengunakan sistem yaitu pemilihan peralatan dan program komputer untuk sistem yang baru. Tujuan dari perancangan ini adalah memberikan gambaran yang jelas kepada pengguna mengenai rancangan yang telah diusulkan. Rancangan program sistemnya dapat digambarkan pada beberapa metode, meliputi Flow Chart Sistem, Data Flow Diargram (DFD), sampai Entity Relaionship Diagram (ERD).

\section{Flowchart Sistem}

Berikut adalah beberapa simbol yang digunakan dalam menggambar suatu flowchart dijelaskan pada gambar 1 .

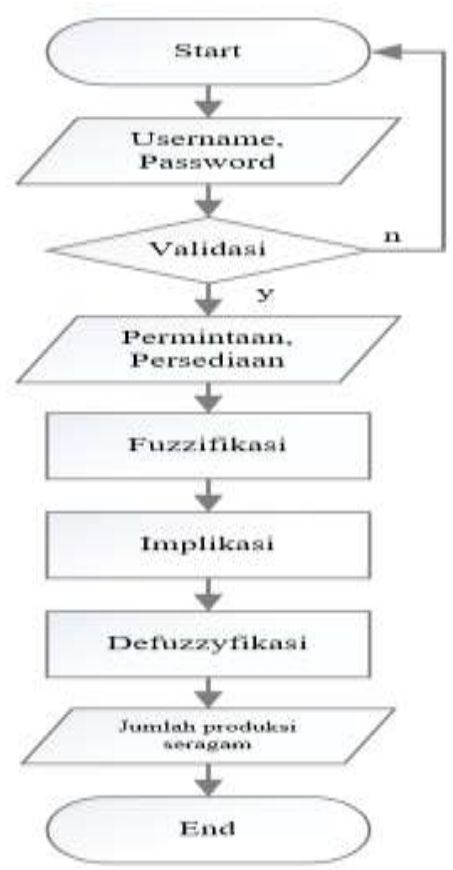

Gambar 1 Flowchart Sistem

Suatu permasalahan dapat diselesaikan dengan flowchart, karena flowchart merupakan bagan alir dari proses penyelesaian masalah yang disusun secara sistematis. Untuk menggambarkan keseluruhan langkah kerja dan sistem yang akan dibuat, maka digunakan bagan alir atau flowchart (Jogiyanto, 2009). Dalam Analisis Estimasi Jumlah Produksi seragam, entitas yang berkaitan adalah admin. Pada Admin didahului dengan menginputkan username dan password. Apabila Login admin sukses maka langsung menuju ke halaman menu, dimana terdapat proses penginputan data produksi dan data user, kemudian dalam proses produksi dimulai dari perhitungan estimasi jumlah permintaan dan persediaan yang kemudian di hitung melalui peroses fuzzifikasi, implikasi dan defuzzifikasi untuk menghasilkan estimasi jumlah produksi seragam. Proses estimasi jumlah produksi seragam diakhiri dengan melakukan proses keluar atau $\log$ out.

\section{Data Flow Diagram (DFD)}


DFD merupakan suatu cara atau metode untuk membuat rancangan sebuah sistem yang mana berorientasi pada alur data yang bergerak pada sebuah sistem nantinya. Dalam pembuatan Sistem Informasi, DFD sering digunakan. Berikut ini adalah DFD yang dijelaskan pada Gambar 2 dan Gambar 3.

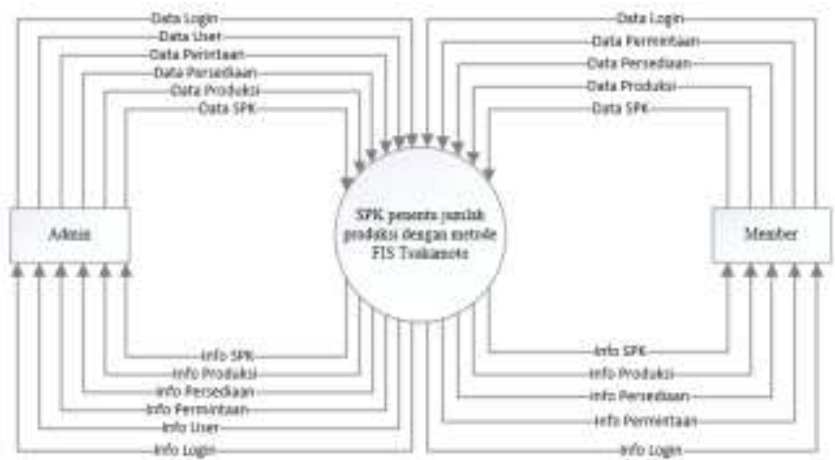

Gambar 2 DFD Level 0

Gambar 2, diagram konteks mempunyai dua entitas yaitu admin dan member. Pada sistem ini, admin menginputkan data user, data permintaan, dan data persediaan kedalam sistem estimasi jumlah produksi seragam, kemudian sistem akan memproses inputan dan memberikan informasi berupa jumlah produksi hasil fuzzyfikasi.

Berikut Gambar 3 Diagram Alir Data level 1.

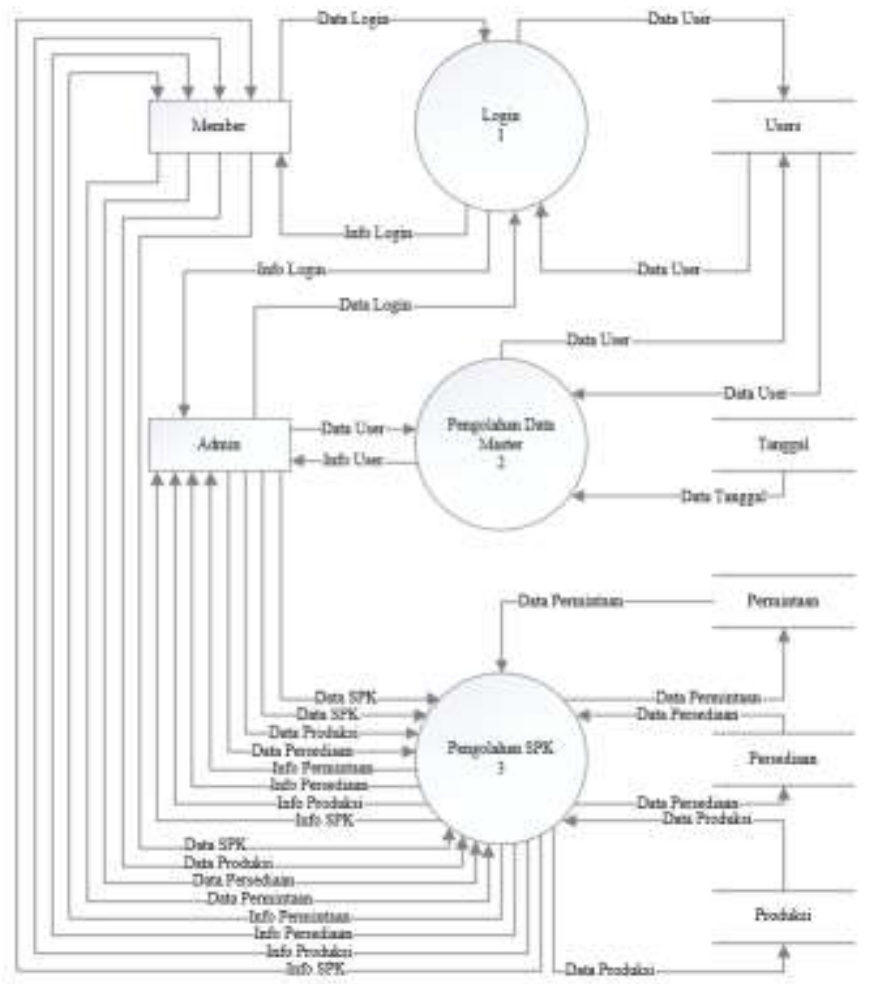

Gambar 3 DFD Level 1

Diagram Alir Data level 1 Aplikasi SPK Dalam Penentuan Jumlah Produksi seragam. Proses yang terjadi adalah admin mengisi data user yang disimpan ke dalam data store 'Users', data permintaan yang disimpan dalam data store 'Pemintaan', data persediaan yang disimpan dalam data store 'Persediaan', data produksi yang disimpan dalam data store 'Produksi', data store 'Permintaan, Persediaan, dan Produksi' 
adalah proses pengolahan data untuk menghitung fuzzifikas, kemudian hasi fuzzifikasi diproses dengan SPK sehingga dapat memberikan informasi kepada admin dan member berupa estimasi jumlah produksi seragam.

\section{Entity Relational Diagram (ERD)}

ERD ( Entity Relationship Diagram) merupakan suatu bentuk yang didasarkan pada dunia nyata yang tersusun atas objek-objek dasar yang disebut entitas yang saling berhubungan antara entitas yang satu dengan yang lain pada sebuah database, seperti Gambar 4.
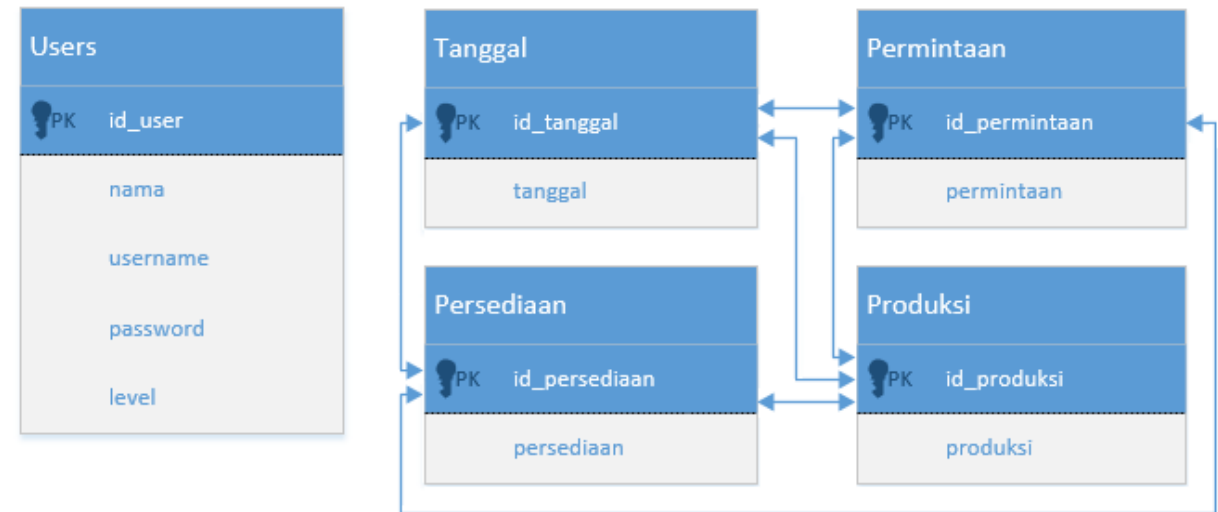

Gambar 4 ERD (Entity Relational Diagram)

\section{F. Kebutuhan Hardware dan Software}

Kebutuhan sistem aplikasi yang digunakan dalam pembuatan SPK dalam menentukan jumlah produksi seragam terdiri dari perangkat keras dan perangkat lunak. Perangkat Keras (Hardware), kebutuhan beberapa perangkat keras yang memadai agar aplikasi tersebut bisa berjalan dengan baik sebagai berikut : Laptop / Personal Komputer, Processor minimal Core ${ }^{\mathrm{TM}} 2$ duo, RAM minimal 2GB, dan Harddisk minimal 100GB.

Perangkat Lunak (Software), Software yang digunakan dalam implementasi sistem ini adalah : Sistem operasi minimal menggunakan Microsoft Windows 7, Bahasa pemrograman PHP (hypertext Preprosessor) adalah Bahasa pemrograman pada Web. PHP adalah tool untuk membuat web dinamis, Database MySQL, selain karena open source program, MySQL juga memiliki kelebihan-kelebihan yang tak kalah bagusnya dengan database server lainnya, Notepad++ sebagi tool pengolah koding untuk membuat Web, dan Aplikasi server menggunakan XAMPP versi 3.2. Terakhir Web browser menggunakan Mozilla Firefox digunakan untuk mengakses aplikasi.

\section{A. Implementasi}

\section{HASIL DAN BAHASAN}

Teknologi yang digunakan dalam pengembangan sistem ini adalah teknologi aplikasi berbasis web. Aplikasi berbasis web dapat membentuk sebuah program yang dapat berdiri sendiri dan dapat dijalankan dalam lingkungan internet. Sehingga dimanapun pengguna (user) berada dapat menggunakan aplikasi ini, dengan mengakses situs tersebut secara cepat dan mudah. Dengan sistem web based ini, diharapkan dapat memberikan kemudahan dalam menentukan jumlah produksi seragam.

Proses pembangunan komponen-komponen pokok sebuah sistem informasi yang sudah di desain perlu dibuat sebuah implementasi. Karena implementasi digunakan sebagai tolak ukur atau pengujian dan analisa hasil dari program yang telah dibuat. Implementasi sistem juga merupakan sebuah proses 
pembuatan dan penerapan sistem secara utuh baik dari sisi perangkat keras maupun perangkat lunaknya. Dan juga tujuan dari pengujian ini adalah untuk mengetahui apakah aplikasi yang telah dibuat sesuai dengan perancangannya. Selain itu juga untuk mengetahui detail jalannya aplikasi serta kesalahan yang ada untuk pengembangan dan perbaikan lebih lanjut. Implementasi ini menjelaskan tentang alur pembuatan dan kegunaan program yang dibuat beserta tampilan desain. Berikut adalah tampilan-tampilan halaman yang ada dalam program yang dibuat.

\section{Halaman Produksi}

Menu 'Produksi' adalah menu yang digunakan untuk menghitung jumlah produksi seragam dengan metode Tsukamoto dengan menggunakan data permintaan dan data persediaan. Jika menu 'Produksi' dipilih, maka program akan menampilkan form produksi seperti terlihat pada Gambar 5.

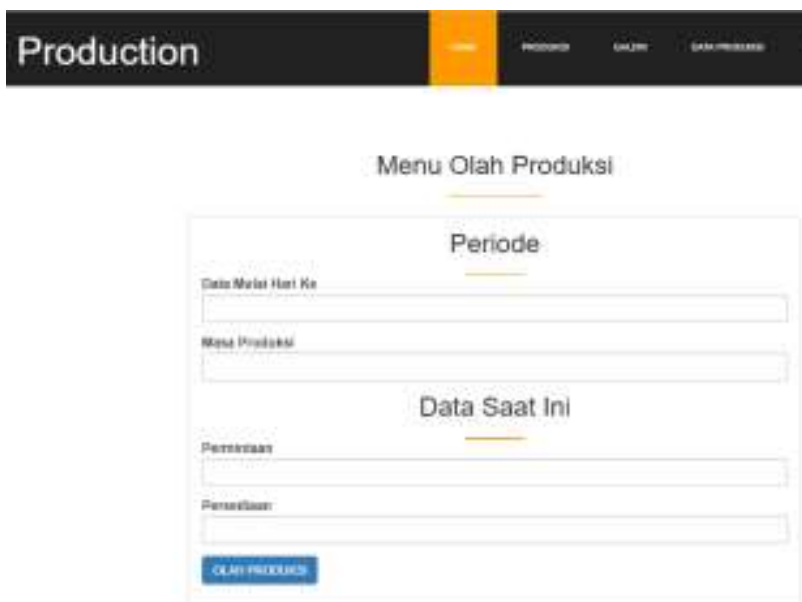

Gambar 5 Menu Produksi

Form olah produksi ini digunakan untuk menghitung jumlah barang yang akan diproduksi dengan metode Tsukamoto. Administrator atau member harus menginputkan hari pertama produksi pada form 'Data mulai hari ke', masa produksi pada form 'Masa produksi', data permintaan saat ini pada form 'Permintaan', dan data persediaan saat ini pada form 'Persediaan'.

\section{Halaman Hasil Perhitungan}

Setelah tombol 'Olah produksi' diklik, maka program akan menampilkan hasil perhitungan berupa nilai variabel-variabel pada perhitungan metode Tsukamoto, jumlah produksi, serta waktu yang dibutuhkan oleh program dalam menghitung jumlah produksi. Hasil perhitungan kemudian seperti terlihat pada Gambar 6. 


\section{Production $-\infty-\infty-\infty$}

Hasil Perhitungan Fuzzy Tsukamoto

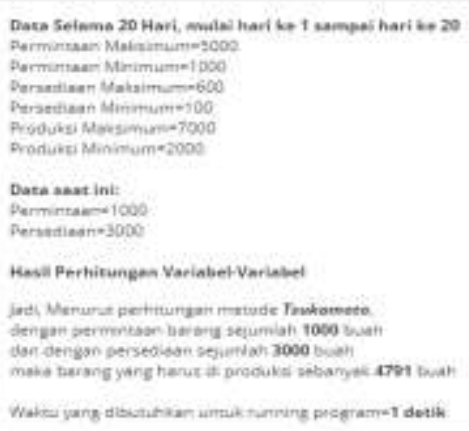

\section{Gambar 6 Halaman Hasil Perhitungan}

\section{Halaman Data Produksi}

Menu 'Data produksi' yaitu menu yang digunakan oleh admin untuk melihat semua data yang ada. Data yang ada pada sistem pendukung keputusan ini adalah data selama 30 hari. Apabila administrator memilih menu 'Data produksi', program menampilkan tampilan seperti terlihat pada Gambar 7.

\section{B. Pengujian Sistem}

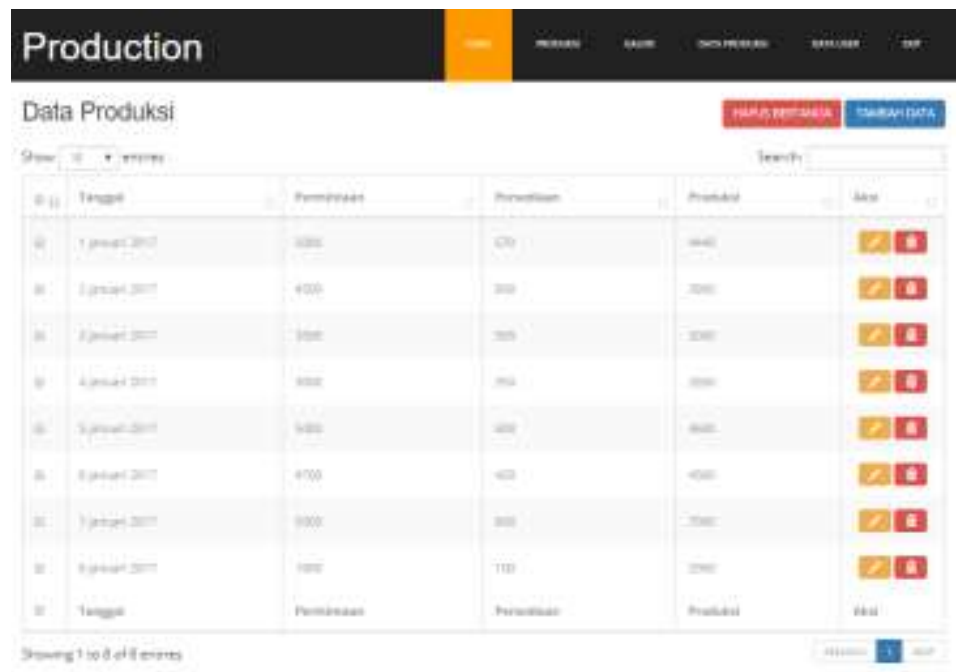

Gambar 7 Halaman Data Produksi

Pengujian aplikasi Sistem pendukung keputusan dalam menentukan jumlah produksi seragam menggunakan metode fuzzy inference system (fis) tsukamoto ini menggunakan metode kuisioner. Pengujian ini dilakukan untuk menentukan bahwa program tersebut sudah layak atau belum untuk digunakan serta telah memenuhi kebutuhan yang diharapakan atau belum.

Pengujian sistem dilakukan secara obyektif dimana diuji secara langsung ke lapangan dengan mengisi kuesioner mengenai kepuasan user dengan kandungan point syarat user friendly dan dibagikan kepada sebagian user dengan mengambil sample sebanyak 10 orang. Dari hasil kuesioner tersebut akan dilakukan perhitungan untuk dapat diambil kesimpulannya terhadap penilaian penerapan sistem yang baru. Hasil pengujian beta sebagai berikut. 
Pengujian Sistem

\begin{tabular}{cccccccccccccc}
\hline \multirow{2}{*}{ No } & Nama & \multicolumn{4}{c}{ Desain Sistem } & \multicolumn{4}{c}{ Kesesuaian Sistem } & \multicolumn{4}{c}{ Kemudahan Sistem } \\
\hline 1. & Agus & 80 & 90 & 60 & 20 & 200 & 90 & 20 & 10 & 120 & 90 & 60 & 10 \\
2. & Yanto & 80 & 90 & 40 & 30 & 160 & 90 & 20 & 20 & 80 & 90 & 40 & 30 \\
3. & Rian & 160 & 60 & 40 & 20 & 80 & 90 & 40 & 30 & 80 & 90 & 60 & 20 \\
4. & Siti & 80 & 90 & 40 & 30 & 80 & 90 & 40 & 30 & 80 & 90 & 60 & 20 \\
5. & Jum & 120 & 90 & 60 & 10 & 80 & 90 & 60 & 20 & 160 & 90 & 20 & 20 \\
6. & Bagas & 160 & 30 & 60 & 20 & 80 & 90 & 60 & 20 & 80 & 90 & 40 & 30 \\
7. & Ana & 120 & 90 & 60 & 10 & 160 & 60 & 40 & 20 & 80 & 90 & 60 & 20 \\
8. & Mita & 160 & 60 & 40 & 20 & 160 & 30 & 60 & 20 & 160 & 60 & 40 & 20 \\
9. & Dian & 80 & 90 & 40 & 30 & 120 & 90 & 60 & 10 & 120 & 90 & 60 & 10 \\
10. & Julia & 120 & 90 & 60 & 10 & 80 & 90 & 40 & 30 & 80 & 90 & 40 & 30 \\
\multicolumn{1}{l}{ TOTAL } & 1160 & 780 & 500 & 200 & 1200 & 810 & 440 & 210 & 1040 & 870 & 480 & 210 \\
\hline
\end{tabular}

Keterangan nilai: $\mathbf{S B}=\mathbf{4 0}, \mathrm{C}=\mathbf{2 0}, \mathrm{B}=\mathbf{3 0}, \mathrm{K}=\mathbf{1 0}$

Prosentase $=\frac{\text { Jumlah }}{\text { Nilai } \text { Total }} \times 100 \%$

a. Nilai total Aspek Desain Sistem $=2620$
1) Kurang
$=200 / 2640 \times 100 \%=7.57 \%$
2) Cukup
$=500 / 2640 \times 100 \%=18.93 \%$
3) Baik
$=780 / 2640 \times 100 \%=29.54 \%$
4) Sangat baik $=1100 / 2640 \times 100 \%=41.66 \%$

b. Nilai total Aspek Kesesuaian Sistem $=2420$
1) Kurang
$=210 / 2660 \times 100 \%=7.89 \%$
2) Cukup
$=440 / 2660 \times 100 \%=16.54 \%$
3) Baik
$=810 / 2660 \times 100 \%=30.45 \%$
4) Sangat baik $=1200 / 2660 \times 100 \%=45.11 \%$

c. Nilai total Aspek Kemudahan Sistem $=3040$

1) Kurang $\quad=210 / 2600 \times 100 \%=8.07 \%$

2) Cukup $\quad=480 / 2600 \times 100 \%=18.46 \%$

3) Baik $\quad=870 / 2600 \times 100 \%=33.46 \%$

4) Sangat baik $=1040 / 2600 \times 100 \%=40 \%$

Berdasarkan hasil kuisioner di atas, dapat ditarik kesimpulan bahwa dilihat dari segi penilaian baik dari desain Sistem diperoleh penilaian baik 29.54\% dan penilaian sangat baik 41.66\%, sedangkan aspek Kesesuaian Sistem memperoleh penilaian baik $30.45 \%$ dan penilaian sangat baik $45.11 \%$, dan dari aspek Kemudahan Sistem dinilai penilaian baik $33.46 \%$ dan penilaian sangat baik $40 \%$.

\section{A. Kesimpulan}

\section{Simpulan Dan SARAN}

Berdasarkan penelitian dan pengujian mengenai Penerapan Metode Tsukamoto (Logika Fuzzy) dalam Sistem Pendukung Keputusan (SPK) untuk Menentukan Jumlah Produksi Seragam Berdasarkan Data Permintaan dan Jumlah Persediaan maka dapat disimpulkan sebagai berikut.

SPK dengan FIS Tsukamoto untuk menentukan jumlah produksi seragam ini, menggunakan tiga komponen, yaitu: model base, database, dan software system. Komponen model base berisi tentang langkah-langkah pada metode Tsukamoto untuk menentukan jumlah produksi. Langkah-langkah yang ditempuh sama dengan langkah-langkah pada kesimpulan nomor 1. Komponen kedua adalah database. Dalam database SPK ini, dibuat 5 tabel, yaitu tabel permintaan, persediaan, produksi, tanggal, dan users. 
Tabel permintaan, persediaan, dan produksi dihubungkan oleh kunci primer id, sedangkan tabel users adalah tabel yang berdiri sendiri, yang digunakan untuk kepentingan login pengambil keputusan. Komponen terakhir adalah software system. Pada komponen software system, komponen model base dan komponen database kemudian dipadukan dengan bahasa pemrograman PHP.

Dalam penerapan metode FIS Tsukamoto untuk menentukan jumlah produksi seragam ini, terdapat tiga langkah yaitu : Langkah pertama mendefinisikan variabel. Ada tiga variabel yang didefinisikan, yaitu: permintaan, persediaan, dan produksi. Setelah variabel didefinisikan, langkah kedua adalah mencari nilai keanggotaan anteseden $(\alpha)$ dan nilai perkiraan barang yang akan diproduksi $(z)$ dari setiap aturan, dengan menggunakan nilai keanggotaan dari setiap himpunan fuzzy. Langkah kedua ini disebut sebagai inferensi. Langkah terakhir adalah menentukan nilai output crisp berupa jumlah barang yang akan diproduksi (Z) dengan cara mengubah input (berupa himpunan fuzzy yang diperoleh dari komposisi aturan-aturan fuzzy) menjadi suatu bilangan pada domain himpunan fuzzy tersebut. Cara ini disebut dengan metode defuzifikasi. Metode defuzifikasi yang digunakan dalam metode Tsukamoto adalah metode defuzifikasi rata-rata terpusat.

Dengan cara Pengujian beta yang dilakukan secara obyektif dimana SPK diuji secara langsung ke lapangan dan mengisi kuesioner mengenai kepuasan admin dan member dengan kandungan point syarat user friendly dan dibagikan kepada karyawan dengan mengambil sample sebanyak 10 orang. Dengan adanya pengujian beta dapat di ketahui bahwa perolehan penilaian baik $29.54 \%$ dan penilaian sangat baik 41.66\%, diberikan oleh 7 dari 10 orang responden yang menyatakan bahwa tampilan sistem ini sudah baik. Kemudahan sistem ini memperoleh prosentase penilaian baik $33.46 \%$ dan penilaian sangat baik 40\% yang dinyatakan oleh 6 dari 10 responden, artinya fitur yang telah disediakan mudah dipelajari dan mudah dipahami oleh admin maupun member, dan proses pengolahan data juga mudah dilakukan.

\section{B. Saran}

Berdasarkan analisis dan kesimpulan dari laporan ini, beberapa saran yang ingin disampaikan antara lain sebagai berikut.

Permasalahan yng diambil pada penerapan metode Tsukamoto untuk menentukan jumlah produksi seragam ini masih sangat sederhana. Masih terdapat cara yang dapat digunakan untuk membuat sistem pendukung keputusan untuk menentukan jumlah produksi lebih baik antara lain: Menambahkan input berupa faktor lain yang mempengaruhi jumlah barang yang akan diproduksi, misalnya jumlah pekerja dan biaya produksi. Menambahkan aturan fuzzy pada inferensinya, sehingga hasil produksi yang diperoleh semakin akurat.

Aplikasi yang dibangun hanya menggunakan salah satu metode fuzzy dalam proses perhitungannya. Sehingga dapat dikembangkan dengan menambahkan metode lain sebagai pilihan perhitungan. Aplikasi yang dibangun di harapkan dapat dijadikan sebagai bahan dalam pengembangan dan penelitian lebih lanjut sehingga mampu menghasilkan suatu sistem baru yang lebih maksimal dengan tingkat keakuratan lebih tinggi dari sistem ini.

\section{Daftar Pustaka}

Daihani, D. U. 2001. Komputerisasi Pengambilan Keputusan : Panduan Langkah demi Langkah Mengembangkan Sistem Pendukung Keputusan Berbasis Komputer. Jakarta : PT. Elex Media Komputindo.

Jogiyanto. 2009. Analisis \& Disain Sistem Informasi: Pendekatan Terstruktur Teori dan Praktek Aplikasi Bisnis. Yogyakrta: Andi.

Setiaji. 2009. Himpunan dan Logika Samar serta Aplikasinya. Yoyakarta: Graha Ilmu. 
Sri Kusumadewi \& Hari Purnomo. 2004. Aplikasi Logika Fuzzy Untuk Sistem Pendukung Keputusan Edisi Pertama. Yogyakarta: Graha Ilmu.

Yuniardi. 2013. Implementasi FIS Menggunakan Metode Tsukamoto Untuk Memprediksi Jumlah Produksi. Yogyakarta: Graha Ilmu. 